3. Волкова, М. Занин // Биология в школе. - 1990. - № 6- С. 53. 5. Зверев И. Д. Общая методика преподавания биологии / И. Д. Звєрєв, А. Н. Мягкова. - . : Просвещение, 1985 - 191 с. 6. Петрова И. Педагогические основы межпредметных связей / И. Петрова. - М., 1985. - 79 с. 7. Скаткин М. Н. Проблемы современной дидактики / М. Н. Скаткин. - 2-е изд. - М. : Педагогика, 1984. - 96 с.

\title{
Віктор Шутько
}

\section{ПРОБЛЕМИ ФІЗИЧНОГО ВИХОВАННЯ ШКОЛЯРІВ ЧЕРЕЗ ПРИЗМУ ПОГЛЯДІВ УЧИТЕЛЯ}

Шутько В. В. Проблеми фізичного виховання школярів через призму поглядів учителя.

У статті розглядаються окремі проблеми сучасного фізичного виховання в школах промислового мегаполісу. Застосований метод анонімного анкетування серед учителів визначив їх професіональний потенціал, рівень і якість викладання предмету, відношення школярів до занять, підстави незадовільного здоров'я та фізичного розвитку школярів.

Ключові слова: учитель, фізичне виховання, професіоналізм, фізичний розвиток, мотив, рухова активність.

Шутько В. В. Проблемы физического воспитания школьников через призму взглядов учителя.

В статье рассматриваются отдельные проблемы современного физического воспитания в школах промышленного мегаполиса. Примененный метод анонимного анкетирования среди учителей определил их профессиональный потенциал, уровень и качество преподавания предмета, отношение школьников к знаниям, основания неудовлетворительного здоровья и физического развития школьников.

Ключевые слова: учитель, физическое воспитание, профессионализм, физическое развитие, мотив, двигательная активность.

Shutko V. V. Problems of physical education in schools in the light of the views of the teacher.

This paper discusses some problems of modern physical education in schools, industrial metropolis. The method of anonymous survey among teachers identified their professional capacity, level and quality of teaching the subject, the ratio of students to the knowledge bases of poor health and physical development of students.

Keywords: teacher, physical education, professionalism, physical development, tune motor activity.

Сучасний стан здоров'я, фізичного розвитку, фізичної підготовки та функціональних можливостей українських дітей турбує все доросле населення країни, починаючи 3 батьків, педагогів, медиків і завершуючи керівниками державних структур.

Ткачук С. [4, с. 307] на основі посилань на роботи Когут I. (2006), Круцевич Т.(2005), Бар-Ор О. (2009) та ін., причинами цих негативних фактів вбачає невідповідність рухової активності більшості школярів фізіологічним нормам, що забезпечують належний рівень фізичного стану дітей і підлітків. 
У сучасних умовах важливим завданням школи в роботі зміцнення здоров'я дітей $є$ прищеплювання учням стійкого інтересу до занять фізичними вправами в навчальному закладі та вдома. У зв'язку з цим необхідно використовувати усі форми фізичного виховання в школі, а також самостійні заняття вдома задля підвищення рухової активності, зміцнення здоров'я покращення фізичної підготовленості підлітків [5, с. 313].

Актуальність указаного напрямку педагогічної діяльності пов'язана 3 низькою ефективністю традиційних підходів до організації навчально - виховного процесу 3 фізичного виховання школярів [3, с. 65], з розв'язанням комплексної проблеми ставлення й подальшого розвитку системи фізичного виховання в сучасній школі [2, с. 10].

Наукова література має достатньо матеріалу пов'язаного 3 виниклою проблемою. Водночас, ми почасти забуваємо дізнатися думку і бачення ситуації, що склалася у провідного учасника цього процесу - вчителя, який одноосібно відповідає за всю спортивно - масову, оздоровчу і навчально-виховну частину фізичного виховання в школі.

Учитель повинен бути на вершині вивчення і розв'язання окресленої проблеми, мати чіткий педагогічний інструментарій, що дасть змогу проаналізувати та ефективно здійснювати процес формування фізичної культури дитини [1, с. 26].

Mema cmammi - здійснити аналіз проблем фізичного виховання в школах промислового мегаполісу, вивчення окремих складників рівня і якості викладання предмета, професіоналізму вчителів, ставлення школярів до занять і причин погіршення фізичного розвитку і здоров'я дітей шкільного віку через призму поглядів учителів фізичної культури.

Збір інформаційного матеріалу проводився методом анкетування. Вибір анкетування 3-поміж учителів був насамперед визначений 3 причини їх безпосередньої обізнаності про всі позитивні та негативні сторони шкільного предмету - фізичне виховання. Для більш правдивих і об'єктивних відповідей учителям було запропоновано надати відповіді в анонімній анкеті.

Інформативність матеріалу розподілялась на декілька модулів на базі яких проводився моніторинг:

1. Кадровий склад і професіональний рівень учителів;

2. Рухове навантаження учнів у шкільному режимі;

3. Адміністративне забезпечення фізичного виховання;

4. Учитель і його предмет;

5. Урок і його зміст;

6. Рівень фізичного розвитку та здоров’я і причини їх погіршення у школярів;

7. Мотивація школярів до занять фізичною культурою.

Результати відповідей учителів засвідчили, що в школах міста, в середньому працює по 2 педагоги 3 фізичної культури. 85\% опитаних мають вищу освіту, водночас не всі 3 них мають спеціальну, кожен другий учитель - жінка. $15 \%$ учителів шкіл є сумісниками. Отже, позитивна сторона добору кадрів - це те, що у школах рівна кількість учителів чоловіків та жінок, що доцільно в плануванні навчального процесу за віково-статевими особливостями учнів і їх інтересів. Проте турбує брак учителів 3 вищою спеціальною освітою і велика кількість сумісників, що природно позначається на якості проведення занять.

Визначаючи рухове навантаження відведене для вивчення предмета «фізична культура» у школі, можна говорити про іiі відповідність передбаченим нормам $\mathrm{MOH}$. 
У позаурочний час учні відвідують шкільні секції, з розрахунку 1 секція на одного вчителя 3 охопленням $17 \%$ учнів від загальної кількості. Та на жаль навіть такий показник $є$ не у всіх школах. У $30 \%$ шкіл міста секційна робота не проводиться, і на думку вчителів через відсутність фінансування цього напрямку роботи з учнями.

Неоднозначну оцінку визначають вчителя і в адміністративному забезпеченні фізичного виховання. Так, на запитання про ставлення адміністрації школи до проблем фізичного виховання позитивну відповідь дали 80,5\%, а негативну $19,5 \%$, проте на питання, чи забезпечує адміністрація школу спортивним інвентарем, негативно відповіли більшість учителів.

Як результат відповідальності керівників за шкільну фізкультуру ми отримали аналогічну відповідь і на питання, чи достатньо спортивного інвентарю у школі. «Так», відповіли тільки 13,2\% вчителів; частково - 35,2\%; та більше половини вчителів шкіл міста відповіло про явний недолік інвентарю.

Покладання провини в ситуації, що склалася, тільки на адміністрацію шкіл можна вважати не зовсім обгрунтованою, оскільки недолік спортивного обладнання відчувають у більшості шкіл. Це розуміють і вчителі, і на питання, яким має бути забезпечення інвентарем, ми отримали такі відповіді: бюджетно-централізованим $84,5 \%$, спонсорським - 13,2 \%, батьківськими внесками $-8,3 \%$, за рахунок здачі об'єктів в оренду $-6,3 \%$. Хоча, на питання, чи здаються в оренду спортивні об'єкти шкіл, учителі відповіли, що 30,3 \% шкіл роблять це постійно.

Причина відсутності необхідного спортивного інвентарю, незадовільного стану спортивних майданчиків, брак устаткування, низька оплата праці відштовхує не тільки молодих фахівців від роботи у школі, але і змінює ставлення до своєї професії викладачів фізвиховання зі стажем (а їх у школах більшість). Так, на запитання про найнеобхідніший шкільний предмет у початковій школі на 1 місце фізкультуру поставили $63,8 \%$ опитаних учителів, на 2 місце - 4,6\%, на 3 місце $25 \%$, а $6,6 \%$ учителів взагалі не внесли фізкультуру в розподіл місць. Адже хто, як не вчитель фізичного виховання знає, що прищеплення любові до фізичної культури, мотивація до занять, фундамент здоров'я починає формуватися вже в дитячому віці.

На питання анкети, чи дотримуються вчителі програмного матеріалу з фізичної культури, 92,4\% викладачів відповіло ствердно, а 7,6\% - негативно. Хоча вчителі, які ввійшли до більшості, висловили додаткову інформацію про неповне дотримання програми, з мотивуванням недостатності матеріальної бази, аварійним станом спортзалів, станом здоров'я дітей, а також наявністю відповідного досвіду, використанням новацій і проведенням додаткових занять 3 аеробіки.

Якщо показник дотримання програми вчителями можна вважати високим, то факт використання розробок уроків має великий розкид відповідей і варіантів. Майже кожен учитель користується кількома розробками (конспектами), що вони і підтвердили у відповідях анкети. Своїми конспектами користуються - 76,6\% вчителів; колег - 29,9\%; інститутів - 47,3\%; а 12,1\% вчителів користуються іншими джерелами.

Відомо, що обов’язковою формою організації занять 3 фізичної культури у школі $є$ урок. Урок має проходити на високому емоційному рівні, 3 достатньою величиною навантаження задля підвищення адаптивних можливостей організму дітей, з різноманітним вмістом уроку та застосуванням методів на ньому, високою загальною щільністю і необхідною моторною. Саме цього і чекають від учителя діти. Але 3 причини масового браку інвентарю та невідповідності стандартам і 
нормам спортмайданчиків, футбол, волейбол i в окремих школах баскетбол, залишаються єдиним руховим пріоритетом для школярів. При цьому футбол тільки для хлопчиків, а волейбол для дівчаток.

I відповідаючи на запитання якому програмному виду спорту віддають перевагу школярі то 27,2\% вчителів відзначили волейбол; 44\% - футбол; 23\% баскетбол; $17,1 \%$ - рухливі ігри; 8,7\% - легку атлетику; 4,6\% - гімнастку; 2,4\% ручний м'яч.

Але низький відсоток, яким відзначений ручний м'яч та неігрові види, пояснюється не відсутністю пріоритетів у школярів, а неможливістю проведення цих видів програмного матеріалу повною мірою.

Сформована ситуація у шкільному спорті привела вчителів до цікавого визначення. На питання, відповідно до якого напрямку, на Ваш погляд, має бути побудуваний урок фізичної культури, загальнорозвивальний (оздоровчий) або тренуючий з програмних видів спорту, то 83\% вчителів віддали перевагу першому варіанту. Подане визначення збігається з рекомендаціями МОН під час введення нової навчальної програми «Фізична культура для загальноосвітніх навчальних закладів. 1-4 класи » (авт. Круцевич Т. та ін, 2011 р.).

За словами авторів програми, вони відмовилися від вивчення видів спорту (як зараз), а взяли за основу фізвиховання види рухів і назвали це «школою руху». Вона дозволяє задовольнити потребу організму в руховій активності, використовуючи види спорту як засобу фізичного виховання, заняття проводити у вигляді гри, що дітям завжди цікаво.

Розуміючи це, 94,8\% учителів підтвердили у своїх анкетах часте використання ігрового методу на уроках, а от інші ефективні методи не користуються у них популярністю. Наприклад, метод кругового тренування використовують: часто $38,5 \%$ вчителів; іноді - 47,1\%; ніколи - 14,4\%. Великі навантаження: часто - $13 \%$; іноді $-50 \%$, ніколи $-37 \%$. Метод змагань: часто $-69 \%$, іноді $-28 \%$, ніколи $-3 \%$.

Часте застосування ігрового методу передбачає високу як загальну, так і моторну щільність уроку, що необхідно для оздоровчої і загальнорозвивальної спрямованості уроку, покращення функціонального стану та фізичного розвитку школярів.

Виходячи із рекомендацій листа $\mathrm{MOH}$, моторна щільність уроку повинна становити не менше $60 \%$, а як правило моторна щільність (МЩ) під час використання ігрового та змагального методів, а так само методу кругового тренування, становить 50-90\%. Отже, можна було б припустити, що вчителями ця задача розв'язується за рахунок відносно високого показника застосування ними цих методів. Однак, під час визначення оптимальної моторної щільності уроку викладачі довели зворотнє. Так 41,1\% учителів оптимальною МЩ вважають 20-50\% рухової активності школяра; для 39,8\% вчителів - 50-60\%, і для 19,1\% учителів оптимальна МЩ склала-60-80\%.

У результаті, як видно 3 цих даних, більше 40\% вчителів утворюють групу, критеріями рівня якої є методична невідповідність, і тільки 19\% підтвердили свою компетентність.

Такі невідповідності виявили і 46,4\% опитаних учителів під час відповіді на питання, чи доводять вони на уроках навантаження до ЧСС 180 уд.в хв., 7,1\% відповіли задовільно; а 46,5\% надали відповідь-іноді.

Отже, можна зробити висновок, що вчителі забули, що таке циклічні навантаження в зоні високої і максимальної інтенсивності за анаеробного типу обміну речовин, які вони використовують практично на кожному уроці, а це біг на 30 м, прискорення по 20 м, стрибки зі скакалкою, циклічні навантаження 3 
максимальною інтенсивністю близько 10 сек та інші, які, у свою чергу, збільшують ЧСС до рівня 170-180 ударів і вище.

Пропоноване навантаження вважається відносно високим і застосовувати його можна 3 дітьми основної медичної групи. Зауважимо, що їх у школах більшість, оскільки з відповідей учителів зрозуміло, що 3,3\% учнів у середньому по школах звільнені від уроків фізичної культури за станом здоров'я, а $36 \%$ дітей вони віднесли до категорії зі слабким фізичним розвитком, яких гіпотетично можна віднести до підготовчої і спеціальної медичних груп.

Школярі, які розподілені медичним працівником навчального закладу в підготовчу та спеціальну медичну групу, за рекомендаціями МОН повинні займатися безпосередньо на уроках 3 отриманням індивідуальних завдань від учителя.

Водночас на питання анкети, чи функціонує у школі спеціальна медична група, 25,7\% вчителів відповіли - постійно, 12\% - іноді, і 62,3\% відповіли - ні.

Відсутність медгрупи вчителі пояснили непідготовленістю фахівців, умовами організації занять, відсутністю додаткових годин і недостатністю необхідної кількості дітей.

Задля визначення причин масового послаблення здоров'я та зниження фізичного розвитку школярів, учителям було запропоновано варіанти, з яких вони могли обрати декілька відповідей. Причини вони побачили в такому:

сім'я, спадковість - 65,6\%; навколишнє середовище - 45,1\%;

байдужість дітей - 39,9\%; технічний прогрес - 39\%;

державні упущення - 37\%; відсутність мотивації до занять - 25,9\%

недостатня кількість спортивних майданчиків і фахівців - 20,7\%;

брак інформації - 10,5\%; фізкультурна безграмотність - 7,8\%;

слабка підготовка педагогів - 6,4\%.

Визначаючи причину слабкого розвитку родину і спадковість як провідну викладачі так само вказали і практичну відсутність інтересу батьків до успіхів дітей у їх руховому розвитку. Високим відсотком зниження фізичного розвитку дітей учителі позначили їх байдужість і відсутність мотиву до занять. Ця тенденція істотно визначилася в анкетному питанні, чи виявляють школярі інтерес до уроків фізичної культури, де вчителі в $82 \%$ випадків відповіли «так» для молодших класів; для середніх класів це - 90\%; для старших класів цей показник знизився до 52 \%. На питання, що є мотивом у школярів для відвідування уроків фізвиховання, 42\% вчителів відповіли - що це обов'язковість присутності і 43\% визначили як мотив отримання оцінок.

Отже, у фізичному вихованні школярів у школах міста актуальною $є$ низка важливих проблем: украй незадовільне фінансове та матеріально-технічне забезпечення; недооцінка педагогічними колективами значення позаурочної спортивно - масової роботи; падіння престижу професії вчителя фізичного виховання, слабка пропаганда здорового способу життя; велика кількість звітної документації і як наслідок розбіжністі між нею і практичною школою; дефіцит фахівців; втрата мотиву до занять фізичною культурою у школярів під час переходу в старші класи.

Учителі обмежуються незначними навантаженнями остерігаючись відповідальності за нещасні випадки, а головними чинниками послаблення здоров'я та фізичного розвитку вважають спадковість, навколишнє середовище, байдужість, відсутність інтересу батьків до успіхів дітей у їх руховому розвитку та дефіцит традицій фізичного виховання в сім’ї. 
Певну частину учителів можна віднести до категорії невідповідності методичної грамотності з причини хибності та некоректності відповідей на питання анкети, пов'язаних з методикою проведення уроків.

\section{Література}

1. Аксьонова О. П. Нова фізична культура: система методів навчання / О. П. Аксьонова // Теорія та методика фізичного виховання. - 2011. - №3. - С. 25-31. 2. Марченко С. І. Оцінка фізичного розвитку хлопців 6-10 років у контексті сучасних завдань фізичного виховання / С. І. Марченко, В.В.Іванов // Теорія та методика фізичного виховання. - 2011. - № 8. - С. 10-13. 3. Пелешко І. М. Показники фізичного розвитку та фізичної підготовленості учнів 1 класів загальноосвітніх навчальних закладів / І. М. Пелешко // Педагогіка, психологія та медико-біологічні проблеми фізичного виховання i спорту: зб.наук.пр./за ред. Срмакова С.С. Х. :ХДАДМ, 2013. - №8. - С. 65-68. 4. Ткачук С. В. Характеристики рухової активності хлопчиків і дівчат молодшого шкільного віку в умовах мегаполісу/ С. В. Ткачук, О. В. Давиденко // Науковий часопис Національного педагогічного університету ім. М. П. Драгоманова. Серія№15 «Науково-педагогічні проблеми фізичної культури / Фізична культура і спорт» / За ред. Г. М. Артюзова. - К. : Вид-во НПУ ім. М. П. Драгоманова, 2013.Том 2 - Випуск 7. - С. 306-311. 5. Франків Є. Є. Позашкільна діяльність учнів середнього шкільного віку та іiі вплив на здоров'я/ Є. Є. Франків // Науковий часопис Національного педагогічного університету ім. М. П. Драгоманова. Серія №15 «Науково-педагогічні проблеми фізичної культури /Фізична культура і спорт»/ За ред. Г. М. Артюзова. - К. : Вид-во НПУ ім. М. П. Драгоманова, 2013. - Том 2 - Випуск 7. - С. 363-368.

Вікторія Яковлєва

\section{СУКУПНІСТЬ КОМПОНЕНТІВ САМОСТІЙНОЇ ЖИТТЕДІЯЛЬНОСТІ ВИПУСКНИКІВ ШКІЛ-ІНТЕРНАТІВ ЯК ОСНОВА ФОРМУВАННЯ ЇХ ЖИТТЕВОЇ КОМПЕТЕНТНОСТІ}

Яковлєва В. А. Сукупність компонентів самостійної життєдіяльності випускників шкіл-інтернатів як основа формування їх життєвої компетентності.

У статті розкривається сутність та зміст життєвої компетентності та самостійної життєдіяльності особистості, характеризуються основні компоненти самостійної життєдіяльності випускників шкіл-інтернатів, аналізується низка типових соціальних моделей їх поведінки та процес оволодіння соціальним досвідом для успішної реалізації в соціумі різних соціальних ролей з опорою на внутрішні ресурси, розглядається процес формування життєвої компетентності названого контингенту як сукупність компонентів самостійної життєдіяльності.

Ключові слова: життєдіяльність, самостійна життєдіяльність, життєва компетентність, випускники шкіл-інтернатів, соціальний досвід.

Яковлева В. А. Совокупность компонентов самостоятельной жизнедеятельности выпускников школ-интернатов как основа формирования их жизненной компетентности.

В статье раскрывается сущность и содержание жизненной компетентности и самостоятельной жизнедеятельности личности, характеризуются основные компоненты самостоятельной жизнедеятельности выпускников школ-интернатов, анализируется ряд типичных социальных моделей их поведения и процесс освоения социальным опытом, с целью успешной реализации в социуме различных 